\title{
Front Matter: Volume 7426
}

, "Front Matter: Volume 7426," Proc. SPIE 7426, Optical Manufacturing and Testing VIII, 742601 (11 September 2009); doi: 10.1117/12.846300

SPIE Event: SPIE Optical Engineering + Applications, 2009, San Diego, California, SPIE. United States 


\section{PROCEEDINGS OF SPIE}

\section{Optical Manufacturing and Testing VIII}

James H. Burge

Oliver W. Fähnle

Ray Williamson

Editors

4-5 August 2009

San Diego, California, United States

Sponsored and Published by

SPIE

Volume 7426

Proceedings of SPIE, 0277-786X, v. 7426 
The papers included in this volume were part of the technical conference cited on the cover and title page. Papers were selected and subject to review by the editors and conference program committee. Some conference presentations may not be available for publication. The papers published in these proceedings reflect the work and thoughts of the authors and are published herein as submitted. The publisher is not responsible for the validity of the information or for any outcomes resulting from reliance thereon.

Please use the following format to cite material from this book:

Author(s), "Title of Paper," in Optical Manufacturing and Testing VIII, edited by James H. Burge, Oliver W. Fähnle, Ray Williamson, Proceedings of SPIE Vol. 7426 (SPIE, Bellingham, WA, 2009) Article CID Number.

ISSN 0277-786X

ISBN 9780819477163

Published by

SPIE

P.O. Box 10, Bellingham, Washington 98227-0010 USA

Telephone +1 3606763290 (Pacific Time) · Fax +1 3606471445

SPIE.org

Copyright (C) 2009, Society of Photo-Optical Instrumentation Engineers

Copying of material in this book for internal or personal use, or for the internal or personal use of specific clients, beyond the fair use provisions granted by the U.S. Copyright Law is authorized by SPIE subject to payment of copying fees. The Transactional Reporting Service base fee for this volume is $\$ 18.00$ per article (or portion thereof), which should be paid directly to the Copyright Clearance Center (CCC), 222 Rosewood Drive, Danvers, MA 01923. Payment may also be made electronically through CCC Online at copyright.com. Other copying for republication, resale, advertising or promotion, or any form of systematic or multiple reproduction of any material in this book is prohibited except with permission in writing from the publisher. The CCC fee code is 0277-786X/09/ $\$ 18.00$.

Printed in the United States of America.

Publication of record for individual papers is online in the SPIE Digital Library.

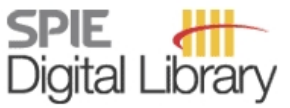

SPIEDigitalLibrary.org

Paper Numbering: Proceedings of SPIE follow an e-First publication model, with papers published first online and then in print and on CD-ROM. Papers are published as they are submitted and meet publication criteria. A unique, consistent, permanent citation identifier (CID) number is assigned to each article at the time of the first publication. Utilization of CIDs allows articles to be fully citable as soon they are published online, and connects the same identifier to all online, print, and electronic versions of the publication. SPIE uses a six-digit CID article numbering system in which:

- The first four digits correspond to the SPIE volume number.

- The last two digits indicate publication order within the volume using a Base 36 numbering system employing both numerals and letters. These two-number sets start with 00, 01, 02, 03, 04, $05,06,07,08,09,0 A, 0 B \ldots 0 Z$, followed by 10-1Z, 20-2Z, etc.

The CID number appears on each page of the manuscript. The complete citation is used on the first page, and an abbreviated version on subsequent pages. Numbers in the index correspond to the last two digits of the six-digit CID number. 


\section{Contents}

vii Conference Committee
ix Introduction

SESSION 1 MULTIPLE SURFACES AND FREEFORM OPTICS

742602 High-resolution measurement of internal interface of optically transparent materials [7426-01]

C.-W. Chang, I.-J. Hsu, Chung Yuan Christian Univ. (Taiwan)

742603 Microfluidic design and fabrication of wafer-scale varifocal liquid lens [7426-02] J. Y. Lee, S. T. Choi, S. Lee, W. Kim, Samsung Advanced Institute of Technology (Korea, Republic of)

742604 Fabrication and characterization of polymer based spatial light modulators [7426-03]

G. Ouyang, K. Wang, M. N. Akram, X. Chen, Vestfold Univ. College (Norway)

742605 Comparison of freeform manufacturing techniques in the production of monolithic lens arrays [7426-04]

G. E. Davis, II-VI Infrared (United States); J. W. Roblee, AMETEK Precitech, Inc. (United States); A. R. Hedges, II-VI Infrared (United States)

$742606 \quad$ Nanometer level freeform surface measurements with the NANOMEFOS non-contact measurement machine [7426-05]

R. Henselmans, TNO Science and Industry (Netherlands); L. Cacace, AC Optomechanix (Netherlands) and Technische Univ. Eindhoven (Netherlands); G. Kramer, TNO Science and Industry (Netherlands); N. Rosielle, M. Steinbuch, Technische Univ. Eindhoven (Netherlands)

\section{SESSION 2 DEVELOPMENTS IN SURFACE FINISHING}

742607 Accuracy of freeform manufacturing processes [7426-06]

G. P. H. Gubbels, B. W. H. Venrooy, R. Henselmans, TNO Science and Industry (Netherlands)

742608 Ultraprecision machining techniques for the fabrication of freeform surfaces in highly integrated optical microsystems [7426-07]

S. Stoebenau, S. Sinzinger, Technische Univ. IImenau (Germany)

742609 Increased UV transmission by improving the manufacturing processes for FS [7426-08]

J. DeGroote-Nelson, T. Nitzshe, D. E. Savage, J. T. Watson, D. K. Henry, A. A. Haefner,

R. A. Wiederhold, Optimax Systems, Inc. (United States)

7426 OA Varying electro-kinetic interactions to achieve predictable removal rates and smooth surfaces on ZnS [7426-09]

J. DeGroote-Nelson, J. A. Drucker, A. A. Haefner, R. A. Wiederhold, Optimax Systems, Inc.

(United States) 
7426 OB Zirconia coated carbonyl iron particle-based magnetorheological fluid for polishing [7426-10]

S. N. Shafrir, OptiPro Systems (United States) and Univ. of Rochester (United States);

H. J. Romanofsky, M. Skarlinski, M. Wang, C. Miao, S. Salzman, T. Chartier, J. Mici,

J. C. Lambropoulos, R. Shen, H. Yang, S. D. Jacobs, Univ. of Rochester (United States)

7426 OC Normal force and drag force in magnetorheological finishing [7426-11]

C. Miao, S. N. Shafrir, J. C. Lambropoulos, S. D. Jacobs, Univ. of Rochester (United States)

7426 OD Contributions of nanodiamond abrasives and deionized water in magnetorheological finishing of aluminum oxynitriden [7426-12]

C. Miao, J. C. Lambropoulos, H. Romanofsky, S. N. Shafrir, S. D. Jacobs, Univ. of Rochester (United States)

7426 OF Simulation and analysis of the polishing process for aspheres [7426-14]

A. Kelm, M. Hänle, R. Boerret, Hochschule Aalen (Germany); S. Sinzinger, Technische Univ. IImenau (Germany)

7426 OG Edge tool influence function library using the parametric edge model for computer controlled optical surfacing [7426-15]

D. W. Kim, W. H. Park, College of Optical Sciences, The Univ. of Arizona (United States); S.-W. Kim, Yonsei Univ. (Korea, Republic of); J. H. Burge, College of Optical Sciences, The Univ. of Arizona (United States)

\section{SESSION 4 SURFACE SHAPING}

7426 Ol Calculating BRDFs from surface PSDs for moderately rough optical surfaces [7426-42] J. E. Harvey, N. Choi, A. Krywonos, College of Optics \& Photonics, Univ. of Central Florida (United States) J. Marcen, E. U. Optica, Univ. Complutense de Madrid (Spain)

\section{SESSION 5 LARGE ASPHERE SURFACING AND TESTING I}

7426 0J Swing-arm optical CMM for aspherics [7426-18]

P. Su, C. J. Oh, R. E. Parks, J. H. Burge, College of Optical Sciences, The Univ. of Arizona (United States)

7426 OK Manufacturing and performance test of a $800 \mathrm{~mm}$ space optic [7426-19]

M. R. Krödel, ECM GmbH (Germany); T. Ozaki, M. Kume, Mitsubishi Electric Corp. (Japan); Y. Y. Yui, H. Imai, H. Katayama, Y. Tange, T. Nakagawa, Japan Aerospace Exploration Agency (Japan)

$7426 \mathrm{OL} \quad$ Fabrication and testing of 1.4- $\mathrm{m}$ convex off-axis aspheric optical surfaces [7426-20] J. H. Burge, S. Benjamin, D. Caywood, C. Noble, M. Novak, C. Oh, R. Parks, B. Smith, P. Su, M. Valente, C. Zhao, College of Optical Sciences, The Univ. of Arizona (United States)

$74260 \mathrm{M}$ Non-null interferometric aspheric testing with partial null lens and reverse optimization [7426-21]

D. Liu, Y. Yang, Y. Luo, C. Tian, Y. Shen, Y. Zhuo, Zhejiang Univ. (China) 
7426 ON Verification procedure for the wavefront quality of the primary mirrors for the MRO interferometer [7426-22]

E. J. Bakker, A. Olivares, New Mexico Tech, Magdalena Ridge Observatory (United States);

R. A. Schmell, R. A. Schmell, D. Gartner, Optical Surface Technologies, LLC (United States);

A. Jaramillo, W.M. Keck Observatory (United States); K. Romero, A. Rael, J. Lewis, Optical

Surface Technologies, LLC (United States)

SESSION 6 LARGE ASPHERE SURFACING AND TESTING II

742600 Monolithic versus segmented primary mirror concepts for space telescopes [7426-23]

S. E. Kendrick, Ball Aerospace \& Technologies Corp. (United States)

7426 OP Measurement of high-departure aspheric surfaces using subaperture stitching with variable null optics [7426-24]

P. Murphy, G. DeVries, J. Fleig, G. Forbes, A. Kulawiec, D. Miladinovic, QED Technologies, Inc. (United States)

$74260 Q \quad$ Stitching interferometry: the practical side of things [7426-25]

M. Bray, MBO-Metrology (France)

7426 OR Research of precision interference locating method for a partial null compensator at aspheric testing [7426-26]

Y. Yang, D. Liu, G. Xin, C. Tian, Y. Luo, Y. Shen, Y. Zhuo, Zhejiang Univ. (China)

7426 OS Fizeau interferometer with spherical reference and CGH correction for measuring large convex aspheres [7426-27]

M. B. Dubin, P. Su, J. H. Burge, College of Optical Sciences, The Univ. of Arizona (United States)

\section{SESSION 7 INTERFEROMETRY}

7426 OU Limits for interferometer calibration using the random ball test [7426-29]

P. Zhou, J. H. Burge, College of Optical Sciences, The Univ. of Arizona (United States)

7426 OV Orthonormal vector polynomials in a unit circle, application: fitting mapping distortions in a null test [7426-30]

C. Zhao, J. H. Burge, College of Optical Sciences, The Univ. of Arizona (United States)

\section{POSTER SESSION}

7426 OY Scanning pentaprism measurements of off-axis aspherics II [7426-32]

P. Su, College of Optical Sciences, The Univ. of Arizona (United States); J. H. Burge, College of Optical Sciences, The Univ. of Arizona (United States) and Steward Observatory, The Univ. of Arizona (United States); B. Cuerden, R. Allen, H. M. Martin, Steward Observatory, The Univ. of Arizona (United States) 
$74260 Z$ Imaging analysis of a novel compound diffractive telescope system [7426-33] J. Yue, Chang chun Institute of Optics (China) and Graduate School of the Chinese Academy of Sciences (China); Z. Lu, H. Liu, W. XU, H. Zhang, Changchun Institute of Optics (China); H. Zhang, Y. Liu, Changchun Institute of Optics (China) and Graduate School of the Chinese Academy of Sciences (China)

742610 High-speed and precision auto-focusing system for direct laser lithography [7426-34] D.-I. Kim, Korea Basic Science Institute (Korea, Republic of); H.-G. Rhee, J.-B. Song, Y.-W. Lee, Korea Research Institute of Standards and Science (Korea, Republic of)

742611 Development of a large ion beam figuring facility for correction of optics up to $1.7 \mathrm{~m}$ diameter [7426-35]

M. Ghigo, Osservatorio Astronomico di Brera (Italy); S. Cornelli, Univ. degli Studi Milano-Bicocca (Italy); R. Canestrari, Univ. degli Studi dell'Insubria (Italy); D. Garegnani, Osservatorio Astronomico di Brera (Italy)

742612 Fabrication of 300-mm silicon reference wafer by using direct laser writer [7426-37] H.-G. Rhee, Korea Research Institute of Standards and Science (Korea, Republic of); D.-I. Kim, Korea Basic Science Institute (Korea, Republic of); S.-K. Hong, J.-B. Song, Y.-W. Lee, Korea Research Institute of Standards and Science (Korea, Republic of)

742613 Laser tracker surface measurements of the 8.4m GMT primary mirror segment [7426-38] T. L. Zobrist, College of Optical Sciences, The Univ. of Arizona (United States); J. H. Burge, College of Optical Sciences, The Univ. of Arizona (United States) and Steward Observatory, The Univ. of Arizona (United States); H. M. Martin, Steward Observatory, The Univ. of Arizona (United States)

742614 Experimental investigation of the dimensions and quality of laser-drilled holes in metals [7426-39]

M. Stafe, C. Negutu, I. Vladoiu, A. N. Ducariu, I. M. Popescu, Univ. Politehnica Bucuresti (Romania)

742615 Parametric and scattering characterization of PDMS membranes for optical applications [7426-40]

A. Santiago-Alvarado, Univ. Technologica de la Mixteca (Mexico); S. Vazquez Montiel, J. Munoz-Lopez, J. Castro-Ramos, Instituto Nacional de Astrofisica (Mexico); J. A. Delgado Atencio, Univ. de la Habana (Cuba)

742616 Modified alignment CGHs for aspheric surface test [7426-41]

J.-B. Song, H.-S. Yang, H.-G. Rhee, Y.-W. Lee, Korea Research Institute of Standards and Science (Korea, Republic of)

Author Index 


\title{
Conference Committee
}

\author{
Conference Chairs
}

James H. Burge, College of Optical Sciences/The University of Arizona (United States) and The University of Arizona/Steward Observatory (United States)

Oliver W. Fähnle, FISBA OPTIK AG (Switzerland)

Ray Williamson, Ray Williamson Consulting (United States)

Program Track Chair

H. Philip Stahl, NASA Marshall Space Flight Center (United States)

Program Committee

Dave Baiocchi, Sandia National Laboratory (United States)

Michael Bray, MBO-Metrology (France)

Andrew R. Clarkson, L-3 Brashear (United States)

Glen C. Cole, L-3 Communications Tinsley Laboratory Inc. (United States)

David A. Content, NASA Goddard Space Flight Center (United States)

Olaf Dambon, Fraunhofer-Institut für Produktionstechnologie (Germany)

Peter J. de Groot, Zygo Corporation (United States)

Roland Geyl, Sagem SA (France)

John E. Greivenkamp, College of Optical Sciences/The University of Arizona (United States)

Stephen D. Jacobs, University of Rochester (United States)

Stephen E. Kendrick, Ball Aerospace \& Technologies Corporation (United States)

Stephen J. Martinek, 4D Technology Corporation (United States)

Gary Matthews, ITT Industries, Inc. (United States)

Chunlin Miao, University of Rochester (United States)

Ted Mooney, ITT Corporation (United States)

Robert E. Parks, Optical Perspectives Group, LLC (United States)

Joseph L. Robichaud, L-3 Communications SSG-Tinsley (United States)

Joanna Schmit, Veeco Instruments Inc. (United States)

Shai N. Shafrir, University of Rochester (United States)

Peter Z. Takacs, Brookhaven National Laboratory (United States)

Martin J. Valente, College of Optical Sciences/The University of Arizona (United States)

David D. Walker, Zeeko Ltd. (United Kingdom)

Xue-jun Zhang, Changchun Institute of Optics, Fine Mechanics and Physics (China) 
Session Chairs

1 Multiple Surfaces and Freeform Optics

Jessica E. DeGroote Nelson, Optimax Systems, Inc. (United States)

2 Developments in Surface Finishing

Ray Williamson, Ray Williamson Consulting (United States)

3 MRF and Aspheres

Jessica E. DeGroote Nelson, Optimax Systems, Inc. (United States)

$4 \quad$ Surface Shaping

Ray Williamson, Ray Williamson Consulting (United States)

$5 \quad$ Large Asphere Surfacing and Testing I

Steve Jacobs, University of Rochester (United States)

$6 \quad$ Large Asphere Surfacing and Testing II

Ray Williamson, Ray Williamson Consulting (United States)

$7 \quad$ Interferometry

Ray Williamson, Ray Williamson Consulting (United States)

Panel Discussion: Issues with Mid-Frequency Surface Errors for Metrology and Fabrication

James H. Burge, Panel Moderator College of Optical Sciences, The University of Arizona (United States)

Leslie L. Deck, Zygo Coproration (United States)

James E. Harvey, CREOL, The College of Optics and Photonics, University of Central Florida (United States)

Jay Kumler, Coastal Optical Systems, Inc. (United States)

Paul E. Murphy, QED Technologies, Inc. (United States) 


\section{Introduction}

This is an exciting time in the development of optical components. At first glance, optical and optomechanical design, substrate casting, surface finishing, and interferometry may appear to be the legacy base technologies upon which standard components are built, while the new developments are to be found in such disciplines as nonlinear effects, biomimetics, and quantum cryptography. A careful reading of these conference proceedings will show that such a superficial view is in error. Extensions of interferometry through stitching, profiling, numerous nulling methods, and computer-generated holograms have led to orders of magnitude improvements in capabilities for aspheric departure with substantially improved lateral and depth resolution. Breakthroughs in the basic science underlying lapping and polishing promise substantial improvements in both removal rate and surface quality across the spectrum of substrate materials. Surface fabrication, new machine types, geometries, controls, and computational models enable the deterministic realization of formerly unreasonable forms and tolerances. Optomechanical design, coupled with new casting, finishing, and testing methods, is creating new generations of large, lightweight telescopes with sensitivities and resolutions beyond our imaginations of only a few years ago. And, optical design is now closing the modeling gaps between tracing ideal rays, polynomial aberrations, and random scatter with a deeper understanding of the effects of statistical and mid-spatial-frequency form errors and their proper specification.

We're pleased to present these manuscripts, proud of our authors, and thankful for their hard and innovative work, the support of their organizations, and the good offices of SPIE.

James H. Burge
Oliver W. Fähnle
Ray Williamson 
Downloaded From: https://www.spiedigitallibrary.org/conference-proceedings-of-spie on 26 Apr 2023

Terms of Use: https://www.spiedigitallibrary.org/terms-of-use 